\title{
Green Oil Production by Hydroprocessing
}

\author{
Song Chen \\ Chemistry center, NICE, Beijing, China \\ Email: chensong@nicenergy.com
}

Received September 13, 2012; revised October 18, 2012; accepted November 2, 2012

\begin{abstract}
Owning to GHG emissions control and prospective future of biofuel, it is encouraged to look for a shift to alternate industrial feedstock and green processes to produce these chemicals from renewable biomass resources. Besides hydrotreating bio-oil or crop oil to produce second generation bio-fuels, the bio-oil can be co-processed in various refining units and it also may lead to the production of green diesel, which is not only an opportunity but also a challenge for petroleum industry. Green oil or green diesel can be produced by co-processing renewable diesel with petroleum oil in present hydroprocressing unit. Many researches and works have been done on co-processing process and related catalyst in the hope of figuring out the mechanism and optimizing the co-processing technology with adding amounts vegetable oils or animal fats to the traditional petroleum refining process to produce green oil. This is a literature review about green oil production by hydroprocessing and co-processing.
\end{abstract}

Keywords: Green Oil; Biofuel; Hydroprocessing; Hydrocracking

\section{Introduction}

It is clear that the fossil resources are not sustainable in long-term social development because of its problem of non-renewable, ecology and environment protection [1]. Thus, oil refining industry has to face strong challenges related to uncertainties about future feedstock and characteristics of oil products around the world. On the one hand, petroleum industry must considerate the increasing refinery versatility and integrate the refining and petrochemical industries. On the other hand, reducing carbon footprints and greenhouse gas (GHG) emissions not only give pressure on petroleum industry but also come up with new opportunity to refineries. Owning to their sources based on photosynthesis, biofuels and bioproducts produced from biomass would not increase the net $\mathrm{CO}_{2}$ in the atmosphere and thus mitigate global warming. It is encouraged to look for a shift to alternate industrial feedstock and green processes to produce these chemicals from renewable biomass resources [2]. There are many benefits for the environment, economy and consumers in using bio-fuels since they are biodegradable and sustainable [3].

Generally, bio-oils are liquid or gaseous fuels made from biomass materials, such as agricultural crops, municipal wastes and agricultural and forestry byproducts via biochemical or thermochemical processes. While biodiesel reduces net carbon dioxide emissions by $78 \%$ on a life-cycle basis when compared to conventional diesel fuel [4], it has also dramatic improvements on en- gine exhaust emissions, which decreases carbon monoxide (CO) emissions by $46.7 \%$, particulate matter emissions by $66.7 \%$ and unburned hydrocarbons by $45.2 \%$ in the combustion of neat biodiesel [5]. Hence, biofuel production along with bioproducts can provide new perspectives of energy in 21st century. Meanwhile, growth of alternative fuels will have major impact on petroleum refining. With global energy demand is expected to grow at CAGR $2.1 \%$, fossil fuels are expected to supply $83 \%$ of energy and $95 \%$ of liquid transportation needs while biofuels are expected to grow at $8 \%-12 \% /$ year [6]. Therefore, based on the consideration on both the abatement of GHG and supplement of worldwide fuel need, it is recommended to have more efficient alternatives based on both renewable and conventional technologies [7]. Conversion of the vegetable oils and animal fats into biodiesel has been undergoing over the past several years. Biofuel can substitute conventional fuels in vehicle engines based on either totally or partially in a blend [8].

Compared with gasoline vehicles, diesel vehicles are naturally $20 \%-40 \%$ more energy efficient, which results in a $10 \%-20 \%$ reduction in GHG emissions. Moreover, using biodiesel and renewable diesel fuels can further reduce carbon dioxide emissions anywhere from $20 \%-60 \%$ [9]. Particularly, as number of vehicles based on petroleum fuels keeps on increasing worldwide, the efforts and researches keep on being hot on new energy and renewable engine fuel and focus on the development of renewable and sustainable resources, green energy, eco-friendly process, etc. in the transportation sector. Co-processing in 
the conventional processing condition in refineries is a good choice for refineries. Hydrodeoxygenation for bio-oil may result in loss of mass for the production of green oil, which the yield from biodiesel production by hydrodeoxygenation is approximately $81 \%$ on a weight basis and higher $92 \%$ on volume basis based on biodiesel of approximately $15 \%$ - 20\% methyl esters in (weight basis) content [10]. Nevertheless, this mass loss can be tolerated or offset because the predominant n-alkane products of HDO have higher energy content in renewable diesel than their precursors of methyl esters. Moreover, green oil derived from bio-oil by hydrogenation process can present great enhancement of cetane number for renewable diesel oil alone with alternative source of energy. Therefore, it seems to be benefit of refineries to co-process bio-oil and conventional petroleum.

Co-processed renewable diesel can be produced and used when an oil company adds small amounts vegetable oils or animal fats to the traditional petroleum refining process to produce diesel fuel. This bio-oil can be co-processed in various refining units which may lead to second generation bio-fuels. Particularly, hydrotreating process plays important roles in producing so called green oil and is commonly used to co-process bio-oil mixed with various petroleum oil. The typical catalysts commonly discussed in the literature are $\mathrm{NiMo} / \gamma-\mathrm{Al}_{2} \mathrm{O}_{3}$ or $\mathrm{CoMo} / \gamma-\mathrm{Al}_{2} \mathrm{O}_{3}[11]$ while catalysts with different metals and/or supports such as CoMo/C [16], reduced $\mathrm{Ni} / \mathrm{SiO}_{2}$ [19], $\mathrm{Pd} / \mathrm{SiO}_{2}$ [20], $\mathrm{Pd} / \mathrm{C}$ [21], $\mathrm{Pt} / \mathrm{C}$ [23], $\mathrm{Rh} / \mathrm{C}$ [23], $\mathrm{Rh} / \mathrm{Al}_{2} \mathrm{O}_{3}[25]$ and etc. were researched.

Furthermore, since alternative feeds of bio-oil are renewable and potentially cheaper than mineral oil, which is involved in, implementing co-processing techniques in petroleum refineries can result in a competitive advantage for both refiners and society. Undoubtedly, co-processing can utilize the existing production and distribution systems for petroleum-based products and avoid the establishment of parallel systems, which reduce the costs of production. However, some problems should be solved and some characteristics should be caught in order to assure the normal running of co-processing when applied in conventional refineries. Most of all, characteristic of oxygen containing in bio-oil is noticeable. Water will generate in the hydrogenation condition. The influence of water on co-processing should be considered as water formed during hydrotreating itself may decrease activity in the reaction [26], although it was stated weak in hydrogenation course. Besides water, $\mathrm{NH}_{3}$ and $\mathrm{H}_{2} \mathrm{~S}$ that generate in the hydrogenation process probably have influences on HDO or even co-processing.

\section{Types of Feedstocks (Type of Bio-Oil)}

Biomass fast pyrolysis liquefaction has been a very important area of research and development for providing biofuel [27]. Bio-oil is a complex derived from biomass and plant oil. In general, biooil is used feedstocks that obtained through conversion by fast pyrolysis and subsequent appropriate upgrading into liquids, which can substitute crude oil in conventional refinery units and afford significant $\mathrm{CO}_{2}$ emission. The name biodiesel was generally been given to transesterified vegetable oil to describe its use as a diesel fuel as this fuel has similar properties to those of diesel produced from crude oil [28]. Commonly accepted biodiesel raw materials include the oils from soy, canola, corn, rapeseed, and palm while new plant oils are used such as mustard seed, peanut, sunflower, and cottonseed. The most commonly used animal fats include those derived from poultry, beef, and pork [29].

Biofuel is highly oxygenated mixture with a great amount of macromolecules, which nearly involve all species of oxygenated organics, such as esters, ethers, aldehydes, ketones, phenols, organic acids, and etc. For raw pyrolisis oil, its average composition is involved 50\% $65 \%$ of organic components, $15 \%-30 \%$ of water and $20 \%$ of colloidal lignin fraction, in which more than 400 different organic components have been detected that can be classified in several groups: organic acids, aldehydes, ketones, furans, phenolic compounds, guaiacols (methoxyphenols), seryngols and sugarbased compounds [30].

Chemically speaking, it is a mixture of mono-alkyl esters of fatty acids, most often obtained from extracted plant oils and/or collected animal fats. In order to make biodiesel form biomass or plant oil and made them an alternative to petroleum-based diesel fuel, transesterification for converting triolein to methyl oleate and hydrodeoxygenation (HDO) for converting them to heptadecane are necessary processes. For the production of green oil, hydrodeoxygenation is a crucial process by which a feedstock that contains double bonds and oxygen moieties is converted to hydrocarbons by saturation of the double bonds and removal of oxygen through reaction of decarboxylation, decarbonylation, dehydration.

\section{Green Oil Based on Hydrotreating}

\subsection{Pyrolysis-Derived Bio-Oil}

Biomass pyrolysis oil was made from biomass pyrolysis process, which also can be called bio-oil, pyrolysis oil, or bio-crude for short. In order to produce bio-oil, a short reactor times and rapid cooling or quenching from the pyrolysis temperatures are required [32]. Thus, biomass pyrolysis oil is not a product of thermodynamic equilibrium. Noticeably, it is possible to improve the properties of bio-oil by hydrotreating and esterifying carboxyl group compounds in the bio-oil. As, by hydrotreating the bio-oil under mild conditions, some carboxylic acid compounds could be converted to alcohols which would esterify with 
the unconverted acids in the bio-oil to produce esters, the properties of the bio-oil could be improved in such a method.

In order to allow FCC co-processing pyrolysis oil, de Miguel Mercader [33] did hydrodeoxygenation of pyrolysis oil with commercial $5 \mathrm{wt} \% \mathrm{Ru} / \mathrm{C}$ catalyst at the conditions of $290 \mathrm{bar}, 230^{\circ} \mathrm{C}-340^{\circ} \mathrm{C}$ and $4 \mathrm{~h}$ reaction time in a autoclave. In spite of the relatively high oxygen content (17 - $28 \mathrm{wt} \%$ on dry basis) and the different properties of the HDO oils, they successfully dissolved $20 \mathrm{wt} \%$ of it in Long Residue and co-processed them by FCC. Near oxygenate-free bio-hydrocarbons were obtained and near normal FCC $44-46 \mathrm{wt} \%$ of gasoline and Light $3-25 \mathrm{wt} \%$ of cycle oil products were given without an excessive increase of undesired coke and dry gas. Noticeably, undiluted HDO oil by catalytic cracking caused much higher coke yields, suggesting the importance of using a refinery feed as a diluent and hydrogen transfer source for co-processing bio-oil. Therefore, as long as the catalytic cracking is done in the presence of a suitable co-feed present in sufficient quantity, the HDO step does not need full deoxygenation. The degree to the reduction of the groups by HDO should be judged by degree to coke formation.

Comparing compound class of oil products for single-stage without catalyst, Rocha [34]researched hydrodeoxygenation during the hydropyrolysis of cellulose with single stage with dispersed iron sulphide catalyst and two-stage process over Ni-Mo catalyst (1st stage 10 $\mathrm{MPa} / 520^{\circ} \mathrm{C}, 2$ nd stage $10 \mathrm{MPa} / 400^{\circ} \mathrm{C}$ ). It was found that the Ni-Mo catalyst in the second stage reduced both the content of oxygen and aromaticity of the oils. when treating oils from pure cellulose that obtained from single stage by $\mathrm{FeS}$ catalysized hydropyrolysis of cellulose, they concluded that: 1) raising the hydrogen pressure from atmospheric to $10 \mathrm{MPa}$ increased the carbon conversion by 10 mole $\%$; 2) the oxygen content of the primary oil was reduced by over $10 \%$ to below $20 \% \mathrm{w} / \mathrm{w} ; 3$ ) the addition of a dispersed iron sulphide catalyst further increased the oil yield at $10 \mathrm{MPa}$ and reduces the oxygen content of the oil by a further $10 \%$.

Grange [35] thought that a two-step processing is necessary for stability of pyrolysis oils. A low temperature hydrotreatment enables stabilization through reactions like olefin, carbonyl and carboxylic groups reduction while a further high temperature hydrotreatment aims at hydrodeoxygenation of phenols and hydrocracking of larger molecules. The tests demonstrated that a full hydrorefining of pyrolytic oils would require a temperature of between $350^{\circ} \mathrm{C}$ and $425^{\circ} \mathrm{C}$ for the elimination of the phenolic and furanic oxygens and the conversion of the heavy molecules. They thought that $\mathrm{H}_{2} \mathrm{~S}$ could promote certain reactions such as the decarboxylation of carboxylic groups and the partial pressure of $\mathrm{H}_{2} \mathrm{~S}$ could be used to control hydrogen consumption. Although $50 \mathrm{wt} \%$ yields in hydrocarbons for deep hydrorefining of pyrolysis oils can be expected, a moderate hydroconversion with partial elimination of oxygen would be more advantageous based on economical consideration.

Zhang [36] separated the bio-oil with a yield of $70 \%$ into water and oil phases and hydrotreated the oil phase over sulphided Co-Mo-P/ $/ \mathrm{Al}_{2} \mathrm{O}_{3}$ in an autoclave filled with tetralin that act asbeing a hydrogen donor solvent. Under the optimum conditions of $360^{\circ} \mathrm{C}$ and $2 \mathrm{MPa}$ hydrogen pressure, the oxygen content was reduced from $41.8 \%$ of the crude oil to $3 \%$ of the upgraded one. Besides, the crude oil was methanol soluble while the upgraded one was oil soluble for the hydrodeoxygenation.

Over a kind of reduced $\mathrm{Mo}-\mathrm{Ni} / \gamma-\mathrm{Al}_{2} \mathrm{O}_{3}(10 \% \mathrm{Ni} / 90 \%$ $\mathrm{Al}$ of molar ratio) catalysts, $\mathrm{Xu}$ [37] tested vacuum pyrolysis of biomass at low pressure of $3 \mathrm{MPa}$ in an autoclave. They firstly evaluated the catalyst by upgrading of model compound (glacial acetic acid) at $373 \mathrm{~K}$, which showed that the reduced catalyst had the highest activity with the acetic acid conversion of $33.2 \%$. Then, after upgrading the raw bio-oil that was produced by vacuum pyrolysis of pine sawdust, the $\mathrm{pH}$ value of the bio-oil increased from 2.16 to 2.84 , the water content from 46.2 $\mathrm{wt} \%$ to $58.99 \mathrm{wt} \%$ and the $\mathrm{H}$ element from $6.61 \mathrm{wt} \%$ to $6.93 \mathrm{wt} \%$. Though the dynamic viscosity decreased a little, the ester compounds in the upgraded bio-oil increased by 3 times. Furthermore, Xu etc. [38], prepared another catalyst, reduced $0.06 \mathrm{w} \% \mathrm{Mo}-10 \mathrm{w} \% \mathrm{Ni} / \gamma-\mathrm{Al}_{2} \mathrm{O}_{3}$ catalysts and reduced it in hydrogen environment at 873 $\mathrm{K}$. When hydrotreating vacuum pyrolysis of biomass at 3 $\mathrm{MPa}$, they attained the maximum conversion of acetic acid $(33.20 \%)$ at $473 \mathrm{~K}$ over such a catalyst. Under mild conditions of $373 \mathrm{~K}$ and $3 \mathrm{MPa}$ hydrogen pressure) for upgrading raw bio-oil, the $\mathrm{pH}$ value of the bio-oil increased from 2.33 to 2.77 , the water content from 35.52 $\mathrm{wt} \%$ to $41.55 \mathrm{wt} \%$ and the hydrogen content $6.25 \mathrm{wt} \%$ to $6.95 \mathrm{wt} \%$.

Over Ru/C catalyst, Wildschut etc. [39] upgraded fast pyrolysis oil in batch reactor at the condition of $350^{\circ} \mathrm{C}$, $200 \mathrm{bar}$ and $4.3 \mathrm{~h}$ to produce liquid transportation fuels. It showed the highest activity for $\mathrm{RuCl}_{3}$ for the catalyst with a ruthenium loading of $5 \mathrm{wt} \%$ in the hydrogenation reaction of fast pyrolysis oil, which gave the $55-30 \mathrm{wt} \%$ of oil yield. However, $\mathrm{H} / \mathrm{C}$ ratio was decreased from 1.24 for fresh $\mathrm{Ru} / \mathrm{C}$ to 1.08 for twice recycled $\mathrm{Ru} / \mathrm{C}$.

\subsection{Vegetable Oil}

Biofuels can be made from vegetable oils hydrogenation, in this way biofuel yields hydrocarbons and is generally performed under strictly defined reaction conditions. Owning to long chain of renewable of green oil, "the vegetable diesel fraction" can be a cetane improver that is a vast impact on vehile sweep gas emission. According 
to Stumborg [40], vegetable diesel fraction can cause a reduction of $69 \%$ and $63 \%$ carbon monoxide and hydrocarbon emission respectively along with relatively small impact on $4 \%$ of NOx emission reduction. Nevertheless, owning to its low oxidation stabilities and poor cold-flow properties, untreated biodiesel is not optimal for its use as diesel fuel. As an emerging process, partial hydrogenation plays a good role in improving the functional behavior of vegetable oils [41]. Typically, this process acts as hydrodeoxidation under the mild reaction conditions such as $100^{\circ} \mathrm{C}-180^{\circ} \mathrm{C}$ and $0.15-0.3 \mathrm{MPa}$ [44], in which $\mathrm{Ni}$ or noble metals supported on silica support are used.

HDO of vegetable oil is significantly hydrogen consuming process and the amount hydrogen consumption is dependent on type of vegetable oil and reaction path that is related to mechanism and kinetic of HDO. Highly saturated feedstocks such as palm oil and animal fats appear to offer advantages in terms of reduced hydrogen requirements. Although a commercial renewable diesel is produced by using palm oil and animal fats as feedstock [45], these saturated feedstocks of vegetable may be different when good low-temperature properties are desired for these products [46]. Camelina oil contains a relatively high amount of unsaturated fatty acid chains (27\% - 40\% C18:3) [47] and can produce hydrocarbons of aviation fuels that make necessary for the low-temperature requirements by presenting more cleavage sites in producing process. Some oils from algae may also contain high amounts of unsaturated chains [48] and has also been reported as feedstocks for the use in aviation [49]. Linseed oil (around 47\% C18:3) may therefore also be suitable [50].

In order to make vegetable oils into hydrocarbons to produce liquid transportation fuel, direct conversion of vegetable oils into hydrocarbons by their total hydrogenation seems to be a promising route [51]. Process for production of diesel fuel components based on the total hydrogenation of vegetable oils has been developed and commercialized by the Finnish company Neste Oil [52]. However, reaction metallurgy makes it difficult to process vegetable oils with high acidity in standard hydrotreating reactors because only non-saturated bonds of triglycerides that are the almost exclusive compounds of vegetable oils are hydrogenated. Typically, the main products for hydrogenation of triglycerides are hydrocarbons (n-alkanes) and by-products are propane, water, $\mathrm{CO}$ and $\mathrm{CO}_{2}$ [53]. More unsaturated feedstocks led to greater formation of cycloalkanes and alkylbenzenes with only comparatively small amounts of shorter-chain alkanes. More saturated feedstocks led to alkanes with the one less or the same number of carbons than in the original fatty acid chains.

For total hydrogenation of triglycerides for vegetable oil, the hydrocarbons are based on two common reaction pathways: hydrodeoxygenation (HDO) and hydrodecarboxylation (HDC). Carbon number will vary based on different pathway: n-Alkanes originating from HDO have the same carbon number as the original fatty acid chain, i.e. even carbon number, typically 16 or 18 while the main reaction by-products of this route are water and propane; hydrocarbons originating from HDC one carbon atom less in the molecule than the original fatty acid chain, i.e. odd carbon number while the dominant by-products are $\mathrm{CO}, \mathrm{CO}_{2}$ and propane. The researches showed that the yield of straight-chain alkanes decreases at temperatures $>350^{\circ} \mathrm{C}$ since the alkanes undergo cracking and isomerization at higher temperatures [54].

\subsubsection{Rapeseed Oil}

Kubička [55] used Refined rapeseed oil (food grade) to investigate the mechanism of deoxygenation of vegetable oils over $\mathrm{Ni}(12.7 \mathrm{w} \%), \mathrm{Mo}(21.8 \mathrm{w} \%)$ and NiMo sulfided catalysts with the condition of $260^{\circ} \mathrm{C}-280^{\circ} \mathrm{C}, 3.5 \mathrm{MPa}$ and $0.25-4 \mathrm{~h}^{-1}$ in a fixed-bed reactor. Figure 1 gives the reaction path of vegetable oil. They found that the rate of disappearance of triglycerides is the highest over the bifunctional catalyst being approximately two and three times higher than that over Mo and Ni catalysts, respectively. In the case of the rate of oxygen disappearance, it is again the highest over $0.3 \mathrm{NiMo}$ catalyst with the rates over Mo and Ni catalysts being 3.5 and 19 times slower. n-heptadecane is formed selectively over $\mathrm{Ni} / \mathrm{Al}_{2} \mathrm{O}_{3}$ while $\mathrm{n}$-octadecane is formed almost exclusively over $\mathrm{Mo} /$ $\mathrm{Al}_{2} \mathrm{O}_{3}$. The $0.3 \mathrm{NiMo}$ catalyst yields both hydrocarbons with n-octadecane being the favored hydrocarbon in the range $50 \%-70 \%$. Apart from the various oxygenated product intermediates, $\mathrm{NiMo} / \mathrm{Al}_{2} \mathrm{O}_{3}$ yielded a mixture of decarboxylation and hydrodeoxygenation hydrocarbon products while $\mathrm{Ni} / \mathrm{Al}_{2} \mathrm{O}_{3}$ yielded only decarboxylation hydrocarbon products and $\mathrm{Mo} / \mathrm{Al}_{2} \mathrm{O}_{3}$ yielded almost exclusively hydrodeoxygenation hydrocarbon products. The effect of $\mathrm{Ni} /(\mathrm{Ni}+\mathrm{Mo})$ atomic ratio in the range 0.2 0.4 on the activity and selectivity was not significant. Šimáček [56] did hydroprocessing of rapeseed oil as a source of hydrocarbon-based biodiesel over Ni-Mo/alumina catalyst in a laboratory flow reactor. It demonstrated that hydroprocessing of rapeseed oil at $360^{\circ} \mathrm{C}$ and $7 / 15 \mathrm{MPa}$ yielded oxygen-free hydrocarbon mixtures. At low temperature of $310^{\circ} \mathrm{C}$, only trace amounts of reactants and intermediates were observed in products and the products contained mostly n-heptadecane and n-octadecane. The organic liquid products (OLPs) contained acyclic saturated hydrocarbons having 14 - 20 carbon atom numbers ranging, among which n-alkanes $\mathrm{C} 17$ and $\mathrm{C} 18$ formed more than $75 \mathrm{wt} \%$. However, the product of hydroprocessed rapeseed oil has limited utilization in the pure form since the pour point of hydroprocessed product goes up higher than $+20^{\circ} \mathrm{C}$. They also made researches 


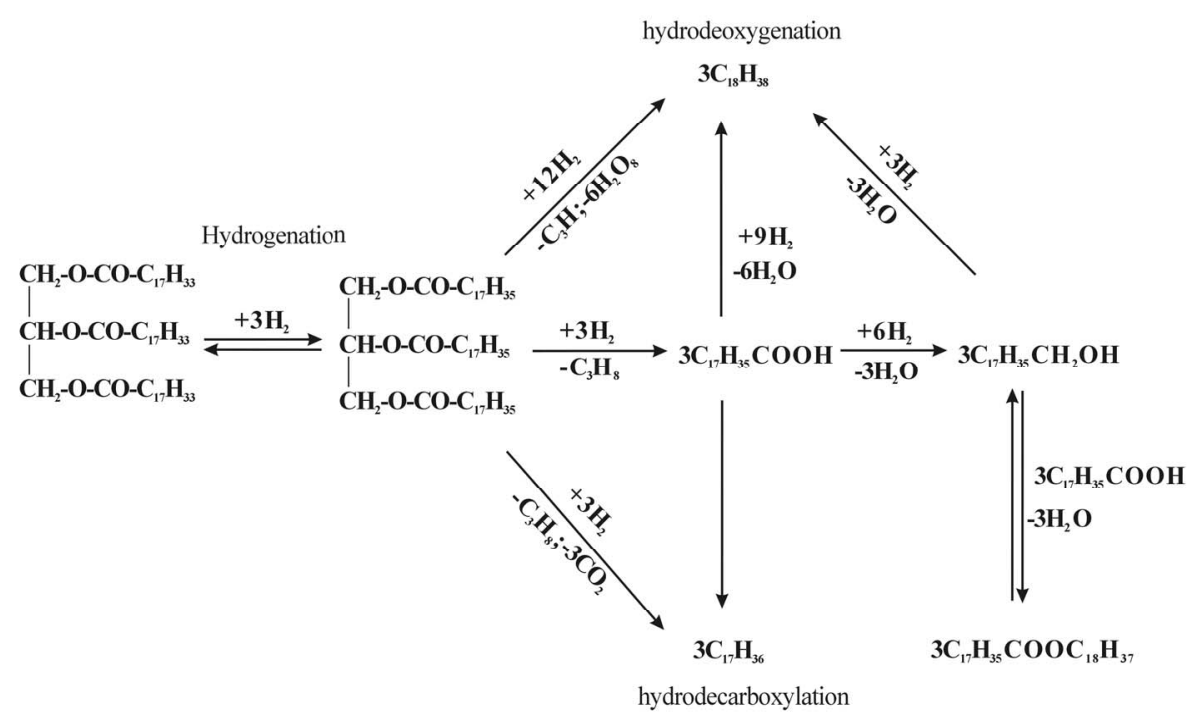

Figure 1. The deoxygenation reaction path of vegetable oil.

on the effect of various $\mathrm{Ni}-\mathrm{Mo} /$ alumina hydrorefining catalysts with different metal loading [57]. It was founded that, at the condition of $260^{\circ} \mathrm{C}-340^{\circ} \mathrm{C}$ under a pressure of $7 \mathrm{MPa}$, no matter what catalyst was used, reaction products contained water, hydrogen-rich gas and organic liquid product (OLP) that the main components were identified as $\mathrm{C} 17, \mathrm{C} 18 \mathrm{n}$-alkanes and i-alkanes. At a low reaction temperature, OLP contained also free fatty acids and triglycerides while, at reaction temperatures higher than $310^{\circ} \mathrm{C}$, OLP contained only hydrocarbons of diesel fuel fraction.

\subsubsection{Hydrocracking}

In hydrocracking process, Šimaček [58] inspected coprocessing of petroleum vacuum distillate containing rapeseed. They used straight-run vacuum distillate (density $0.934, \mathrm{~S} 1.10 \mathrm{w} \%, \mathrm{~N} 0.17 \mathrm{w} \%, 350^{\circ} \mathrm{C}-650^{\circ} \mathrm{C}$ ) and the same fraction containing $5 \mathrm{w} \%$ of rapeseed $(90 \mathrm{w} \%$ of unsaturated $\mathrm{C} 18$ fatty acids chains, $5 \mathrm{w} \%$ of palmitic acid chains and $5 \mathrm{w} \%$ of other acids chains, water content $460 \mathrm{mg} / \mathrm{kg}$ ). The commercial Ni-Mo catalyst was used to be tested on the condition of $400 / 420^{\circ} \mathrm{C}$, hydrogen pressure $18 \mathrm{MPa}$, LHSV $1.0 \mathrm{~h}^{-1}$ and $\mathrm{H}_{2} /$ oil 1000 in a bench-scale flow reactor. It was demonstrated that the product of co-processing obtained at $400^{\circ} \mathrm{C}(18 \mathrm{MPa})$ contained significantly larger amount of n-alkanes $\mathrm{C} 17$ and $\mathrm{C} 18$ than the product obtained from rapeseed-oil-free raw material. When co-processed at $420^{\circ} \mathrm{C}$, low-temperature properties (cloud point $23{ }^{\circ} \mathrm{C}$, CFPP $24{ }^{\circ} \mathrm{C}$ ) were almost similar to those of gas oil obtained from pure petroleum raw material processing.

\subsubsection{Canola Oil}

Kwon [59] used conventional NiMo/g- $-\mathrm{Al}_{2} \mathrm{O}_{3}$ to treat ca- nola oil at the conditions of $18.25-85.13$ bar initial cold hydrogen pressure and $300^{\circ} \mathrm{C}-400^{\circ} \mathrm{C}$ in batch reactor. They found that canola oil is converted mainly into heptadecane and octadecane with heptadecanic acid is formed as a major intermediate product. With hydrogen pressures elevating, reaction time prolonging and $\mathrm{H}_{2}$ pressure increasing, consumption of $\mathrm{H}_{2}$ increased and gave more formation of heptadecane and octadecane. Particularly pointed out, they also found that formation of heptadecane and octadecane, and consumption of hydrogen are higher with wrist-action shaking than horizontal orbital shaking, suggesting hydrodynamics of three phase mixtures consisting affects significantly conversion of canola oil and distributions of reaction products. Moreover, Kwon used methyl laurate to investigate the hydrodeoxygenation of liquid biomass. They found that methyl laurate is converted mainly to undecane and dodecane with lauric acid is formed as a major intermediate product. Formation of undecane, dodecane, and $\mathrm{CH}_{4}$ increases as $\mathrm{H}_{2}$ pressure increases while they increases as reaction temperature increases over the temperature range of $300^{\circ} \mathrm{C}-350^{\circ} \mathrm{C}$ and decreases as reaction temperature increases over the temperature range of $350^{\circ} \mathrm{C}$ $375^{\circ} \mathrm{C}$. It also was found that wrist action shaking was better than horizontal orbital shaking.

Monniera [60] used canola oil to investigate the hydrodeoxygenation of oleic acid in terms of fatty acid conversion with catalyst nitrides of molybdenum, tungsten and vanadium supported on $\mathrm{Al}_{2} \mathrm{O}_{3}$ that was prepared by temperature programmed reaction with $\mathrm{NH}_{3}$. The catalyst was tested on the condition of $380^{\circ} \mathrm{C}-410^{\circ} \mathrm{C}$ and 7.15 $\mathrm{MPa} \mathrm{H}_{2}$. Based on the proposed reactions as shown in following Fig, oxygen can be removed from oleic acid $\left(\mathrm{C}_{17} \mathrm{H}_{33} \mathrm{COOH}\right)$ as water by hydrodeoxygenation of reac- 
tion (1), as $\mathrm{CO}$ and $\mathrm{H}_{2} \mathrm{O}$ by hydrodecarbonylation of reaction (2) or as $\mathrm{CO}_{2}$ by hydrodecarboxylation of reaction (3). Compared to decarbonylation and decarboxylation, the supported molybdenum nitride favored the hydrodeoxygenation of oleic acid to $\mathrm{n}-\mathrm{C}_{18} \mathrm{H}_{38}$. At $400^{\circ} \mathrm{C}$ and 8.35 $\mathrm{MPa} \mathrm{H}_{2}$ over $\mathrm{Mo}_{2} \mathrm{~N} / \mathrm{Al}_{2} \mathrm{O}_{3}$, a $450 \mathrm{~h}$ long hydrotreating test of canola oil indicated that oxygen removal exceeded $90 \%$ and the yield of diesel fuel ranged between 38 and $48 \mathrm{wt} \%$ based on liquid feed.

$$
\begin{gathered}
4 \mathrm{H}_{2}+\mathrm{C}_{17} \mathrm{H}_{33} \mathrm{COOH} \rightarrow \mathrm{n}-\mathrm{C}_{18} \mathrm{H}_{38}+2 \mathrm{H}_{2} \mathrm{O} \\
2 \mathrm{H}_{2}+\mathrm{C}_{17} \mathrm{H}_{33} \mathrm{COOH} \rightarrow \mathrm{n}-\mathrm{C}_{17} \mathrm{H}_{36}+\mathrm{CO}+\mathrm{H}_{2} \mathrm{O} \\
1 \mathrm{H}_{2}+\mathrm{C}_{17} \mathrm{H}_{33} \mathrm{COOH} \rightarrow \mathrm{n}-\mathrm{C}_{17} \mathrm{H}_{36}+\mathrm{CO}_{2}
\end{gathered}
$$

\subsubsection{Sunflower Oil}

\section{Hydrocracking}

With adopting a bifunctional catalyst of Pd/SAPO-31, Oleg etc. [61] treated sunflower oil at the condition of $310^{\circ} \mathrm{C}-360^{\circ} \mathrm{C}$, WHSV $0.9-6 \mathrm{~h}^{-1}$ and pressure of 2.0 $\mathrm{MPa}$. Test showed that, at temperatures $320^{\circ} \mathrm{C}-350^{\circ} \mathrm{C}$, liquid reaction product contained only hydrocarbons. Increasing the reaction temperature or decreasing the oil feed rate promoted the decarboxylation/decarbonylation reactions, thus increasing the $\mathrm{C}_{17} / \mathrm{C}_{18}$ ratio. Simultaneously, the hydroprocessing of sunflower oil with the $\mathrm{Pd} / \mathrm{SAPO}-31$ catalyst provided isomerization of the formed n-alkanes, suggesting that the $\mathrm{Pd} / \mathrm{SAPO}-31$ could be a perspective catalytic system for the one-stage hydroconversion of vegetable oil to produce hydrocarbonbased biodiesel with improved low-temperature properties. However, Pd/SAPO-31 catalyst demonstrated high initial activity but fast deactivation after several hours of operation.

Hancsók [62] adopted Pt/HZSM-22/ $\mathrm{Al}_{2} \mathrm{O}_{3}$ catalysts $(0.25 \%-1.1 \%$ platinum $)$ to investigate the isomerization of pre-hydrogenated sunflower oils (PHSO) at the condition of $280^{\circ} \mathrm{C}-370^{\circ} \mathrm{C}$, pressures of $35-80$ bar, LHSV $1.0-4.0 \mathrm{~h}^{-1}$ and $\mathrm{H}_{2}$ /oil $250-400$. The investigated $\mathrm{Pt} / \mathrm{HZSM}-22 / \mathrm{Al}_{2} \mathrm{O}_{3}$ catalysts seemed to be suitable for the isomerization of pre-hydrogenated sunflower oils with yield of liquid products $>90 \%$. The obtained products have high cetane numbers $(81-84)$ and good cold flow properties (CFPP $10^{\circ} \mathrm{C}-14^{\circ} \mathrm{C}$ ). But it is important to select the severity of the pre-hydrogenation for getting a pre-hydrogenated vegetable oil in the first catalytic stage that contains as low amount of oxygen as possible. The favorable process conditions of isomerization of prehydrogenated sunflower oils (content of organically bonded oxygen $>100 \mathrm{ppm}$ ) on the preferred $0.55 \%$ Pt/HZSM-22 are the following: $\mathrm{T}=320-330{ }^{\circ} \mathrm{C} ; \mathrm{p}=50$ - 60 bar; LHSV $=2.0-3.0 \mathrm{~h}^{-1}, \mathrm{H}_{2} / \mathrm{HC} 300 \mathrm{Nm}^{3} / \mathrm{m}^{3}$.

\subsubsection{Palm Oil}

By hydroprocessing crude palm oil over $\mathrm{NiMo} / \mathrm{gAl}_{2} \mathrm{O}_{3}$ catalyst, Guzman [63] obtained high cetane index renewable diesel at the conditions of 40 bar hydrogen pressure, $350^{\circ} \mathrm{C}$, LHSV of $2 \mathrm{~h}^{-1}$ abd $\mathrm{H}_{2} /$ oil $\sim 500$. The product gave the 92.54 of cetane index while its density was from $0.9152 \mathrm{~g} / \mathrm{ml}$ to 0.7882 , acidity from $7.392 \mathrm{mg}$ $\mathrm{KOH} / \mathrm{g}$ to 1.50 and kinematic viscosity at $40^{\circ} \mathrm{C}$ from $40.33 \mathrm{~mm}^{2} / \mathrm{s} 3.6918$. Hydroprocessing of crude palm oil has resulted in a highly paraffinic renewable diesel with excellent cetane index even when operating at low reaction pressures. At lower pressures, hydrodeoxygenation cannot be fully reached and the appearance of intermediates as $\mathrm{C}_{16}-\mathrm{C}_{18}$ alcohols, $\mathrm{C}_{16}-\mathrm{C}_{18}$ acids and esters were preliminary identified in the reaction product. Times of stream (TOS) experiments have shown that conventional hydrotreating catalyst suffers of slight deactivation. It was thought that 60 bar perhaps was economical.

\subsection{Waste Cooking Oil}

Kubička [64] researched deactivation of HDS catalysts in deoxygenation of rapeseed oils by testing various rapeseed oils with different degree of upgrading, including refined rapeseed oil (RRO), RRO containing $0.5 \mathrm{wt} \% \mathrm{~S}$ (in the form of DMDS), RRO containing $1 \mathrm{wt} \% \mathrm{~S}$. Over sulfided $\mathrm{CoMo} /-\mathrm{Al}_{2} \mathrm{O}_{3}$ catalyst $(3.0 \mathrm{wt} \% \mathrm{CoO} / 13.5 \mathrm{wt} \%$ $\mathrm{MoO}_{3}$ ) and at the conditions of $310^{\circ} \mathrm{C}$, WHSV $2 \mathrm{~h}^{-1}$ and hydrogen pressure $3.5 \mathrm{MPa}$, rapeseed-oil-based feedstocks have low rate of deactivation. Trap grease, a very specific waste stream from vegetable oils processing, caused severe catalyst deactivation since all deoxygenation activity was lost within the first 48 hours on stream. They thought the trap grease most likely to cause catalyst deactivation by coking as it contains significant amounts of phosphorus together with free fatty acids while the high concentration of alkalis in waste rapeseed oil was the main reason for increased deactivation. Continuous added sulfur agent (DMDS) ensured significantly slower catalyst deactivation and presence of $\mathrm{H}_{2} \mathrm{~S}$ lowered considerably hydrodeoxygenation/decarboxylation ratio.

\section{Green Oil Research on Model Compounds}

When producing green oil under hydrotreating conditions, oxygenated compounds will mostly react through hydrodeoxygenation (HDO) route which means $\mathrm{C}-\mathrm{O}$ bonds cleavage and production of water. In order to direct the choosing of process condition and influence on co-processing operating, it is worthwhile knowing exactly what happens during htdrotreating biofuel. Among these O-containing compounds containing in biofuel, the highly representative guaiacol molecule (2-meth-oxyphenol) presents the interest since it possesses two different oxygenated functions (phenolic and methoxy group), in which the first one is considered as the most difficult C-O bond to cleave [65]. Thus, this pure model com- 
pound has been used as a probe molecule in the studies on hydrodeoxygenation [66].

Basically, bio-fuel was made into hydrocarbons by two reaction pathways: 1) hydrodeoxygenation (HDO) and 2) hydrodecarboxylation (HDC). The n-Alkanes originating from HDO have the same carbon number as the original fatty acid chain while the main by-products of this reaction route are water and propane. The hydrocarbons originating from HDC have an odd carbon number with one carbon atom less than the original fatty acid chain while the dominant by-products are $\mathrm{CO}, \mathrm{CO}_{2}$ and propane [67]. The thermodynamic balance predictions suggest that $\mathrm{C}_{18}$ hydrocarbons are the main reaction products and that their concentration is affected by temperature and particularly by pressure.

Catalysts can possess different activities depending on the structure of the feeds. $\mathrm{NiMo} / \mathrm{Al}_{2} \mathrm{O}_{3}$ has a higher decarboxylation activity than $\mathrm{CoMo} / \mathrm{Al}_{2} \mathrm{O}_{3}$ with hydrogenation of carboxylic groups requiring temperatures around $300^{\circ} \mathrm{C}$. Decarboxylation of inactivated carboxylic acids reacts at elevated temperature and pressure because, although exothermic, requires high transition state energies. Carboxylic acids and esters react at similar rates with similar reactivity. Alumina-supported catalysts exhibited higher rates of decarboxylation and deesterification compared to carbon and silica, in which the acidity of the support influences the formation of active sites for decarboxylation and hydrogenation of carboxyl groups.

Echeandia [68] used phenol to detect synergistic effect between nickel and tungsten oxide species supported on activated carbon in phenol hydrodeoxygenation (HDO). The catalyst was Ni-W-P/C (Ni $2.5 \%, \mathrm{~W} \sim 5.5 \%$, P or $\mathrm{Si}$ $0.4 \%-1 \%$ ) and was heat treated in $\mathrm{H}_{2}$ flow at soft conditions of $673 \mathrm{~K}$ for $4 \mathrm{~h}$. In order to study the effect of tungsten precursor (silicotungstic (HSiW), phosphotungstic (HPW), and tungstic (HW) acids) on the activity of partially reduced Ni-W/AC catalysts, tests were done on the conditions of hydrogen pressure of $1.5 \mathrm{MPa}$, temperatures ranging from 423 to $573 \mathrm{~K}$ and WHSV $0.5 \mathrm{~h}^{-1}$ in a flow fixed-bed reactor. The results showed that as following: 1) regardless of the tungsten precursor, after $\mathrm{Ni}$ incorporation to the base W/AC system, a large enhancement in catalyst performance was observed; 2) lower coke formation on the surface of AC with respect to classical alumina support; 3 ) regardless of the reaction temperature, reaction probably occurs via two direction pathways based on a) a hydrogenation (HYD) of phenol's aromatics ring (main reaction route) leading to formation of cylohexane, cyclohexene, cyclohexanol and methylcyclopentane and b) a direct cleavage of the C-O bond leading to benzene formation; 4) total elimination of the O-containing compounds was archived in the $\mathrm{HDO}$ reaction at $573 \mathrm{~K}$ over oxide $\mathrm{Ni}-\mathrm{W}(\mathrm{P}) / \mathrm{AC}$ and Ni$\mathrm{W}(\mathrm{Si}) / \mathrm{AC}$ catalysts.
Boda [69] investigated the hydroconversion process of triglycerides to acyclic aliphatic hydrocarbons by using triglycerides of biological origin, tricaprylin (TC) and caprylic acid (CA) as feeds. The catalyst was $3 \mathrm{wt} \%$ $\mathrm{Pd} / \mathrm{C}, 11 \mathrm{wt} \% \mathrm{Mo}-3 \mathrm{wt} \% \mathrm{Ni} / \mathrm{Al}_{2} \mathrm{O}_{3}$ and each of the catalysts tested was activated in situ in hydrogen flow at $450^{\circ} \mathrm{C}$ for $3 \mathrm{~h}$ and tested in a flow of (TC or CA) $/ \mathrm{H}_{2} / \mathrm{He}$ mixture to maintain the total pressure at 21 bar while the partial pressures of reactants could be changed. The condition of WHSV was $6 \mathrm{~h}^{-1}, \mathrm{H}_{2} / \mathrm{CA}$ molar ratio $1-20$, reaction temperature $300^{\circ} \mathrm{C}-400^{\circ} \mathrm{C}$ for the TC or CA. They assumed probably consecutive steps as hydrogenolysis (HYS) of TC to CA and propane with followed by hydrodeoxygenation (HDO) of the CA intermediate. The overall reaction rate was governed by the HDO reaction. They also distinguished two distinct HDO routes: 1) hydrodecabonylation and 2) reduction of oxygen. They found that, over $\mathrm{Pd} / \mathrm{C}$ catalyst, the prevailing reaction route of CA hydroconversion was the decarbonylation that gives mainly $\mathrm{C} 7$ alkane (one carbon atom shorter than the reactant acid) and $\mathrm{CO}$ while, over $\mathrm{Ni}-\mathrm{Mo} / \mathrm{Al}_{2} \mathrm{O}_{3}$ catalysts, the $\mathrm{HDO}$ proceeded in consecutive $\mathrm{H}_{2}$ addition and dehydration steps giving predominantly straightchain $\mathrm{C}_{8}=$ alkenes, $\mathrm{C}_{8}$ alkanes and water. Reaction route 1) passes through formic acid intermediate that rapidly decomposes to $\mathrm{CO}$ and $\mathrm{H}_{2} \mathrm{O}$ in the presence of $\mathrm{H}_{2}$ while reaction route 2) passes through acid-to-alkane intermediates to give alcohol and traces of aldehyde.

Kubičková [70] used a series of compounds representing model compounds of vegetable oils to do research on decarboxylation of vegetable oils, including stearic acid, ethyl stearate and tristearine. He adopted a commercial activated carbon supported palladium (5 wt $\%$ ) catalyst that was reduced in situ at $200^{\circ} \mathrm{C}$ for $2 \mathrm{~h}$ in a constant flow of hydrogen before tested. The test conditions were $300^{\circ} \mathrm{C}-360^{\circ} \mathrm{C}$ and $17-40$ bar pressure. The results demonstrated that the same final product, n-heptadecane, was obtained for the tested model compounds, including stearic acid, ethyl stearate, and tristearine representing vegetable oils. And the side products consisted of positional isomers of heptadecenes and constitutional isomers of undecylbenzenes. Interestedly, under slightly higher hydrogen pressure the formation of aromatic hydrocarbons was suppressed. Further increase of the hydrogen partial pressure, however, suppressed the stearic acid conversion. Increasing the reaction temperature significantly improved the conversion of ethyl stearate, leading at the same time to enhanced formation of undesired aromatics.

Smejkala [71] choosed tristearate as a model compound to represent vegetable oils in the calculations for a basic thermodynamic analysis of the reaction system whose predictions were compared to the experimental observations of total hydrogenation of rape-seed oil. His 
estimations suggested that the hydrogen diffusivity was important for reaction because it was limited by the liquid film on catalyst particles.

Vitu [72] used tristearate as a thermodynamic model for the total hydrogenation of tristearate at the condition of temperatures $250^{\circ} \mathrm{C}-450^{\circ} \mathrm{C}$, hydrogenation pressures 7 - 70 bar and $\mathrm{H}_{2}$-inert gas/feed roughly 100:1 (mol/mol). Based on the works on thermodynamics done by previous researchers [73], the tests showed the thermal capacity of organic compounds related to the various groups of bio-fuel, which explained the basic reaction mechanism of the proposed catalytic transformation summarized in Equations (1)-(4) as shown in the following.

$$
\begin{gathered}
\left(\mathrm{CH}_{2}\right)_{2} \mathrm{CH}\left[\left(\mathrm{CH}_{2}\right)_{16}\right]_{3}(\mathrm{COO})_{3}\left(\mathrm{CH}_{3}\right)_{3}+3 \mathrm{H}_{2} \\
=3 \mathrm{C}_{17} \mathrm{H}_{36}+\mathrm{C}_{3} \mathrm{H}_{8}+3 \mathrm{CO}_{2} \\
\left(\mathrm{CH}_{2}\right)_{2} \mathrm{CH}\left[\left(\mathrm{CH}_{2}\right)_{16}\right]_{3}(\mathrm{COO})_{3}\left(\mathrm{CH}_{3}\right)_{3}+12 \mathrm{H}_{2} \\
=3 \mathrm{C}_{18} \mathrm{H}_{38}+\mathrm{C}_{3} \mathrm{H}_{8}+6 \mathrm{H}_{2} \mathrm{O} \\
\mathrm{CO}_{2}+\mathrm{H}_{2}=\mathrm{CO}+\mathrm{H}_{2} \mathrm{O} \\
\mathrm{CO}_{2}+4 \mathrm{H}_{2}=\mathrm{CH}_{4}+2 \mathrm{H}_{2} \mathrm{O}
\end{gathered}
$$

Smejkala [74] demonstrated the importance of pressure on reaction path by using rape-seed oil to make modeling research for total triglyceride hydrogenation over commercial sulfided $\mathrm{Ni}-\mathrm{Mo} / \mathrm{Al}_{2} \mathrm{O}_{3}$ and reduced $\mathrm{Ni} / \mathrm{Al}_{2} \mathrm{O}_{3}$ in fixed-bed reactor with reaction temperature being $240^{\circ} \mathrm{C}$ - $360^{\circ} \mathrm{C}$, pressure 0.5 - $8 \mathrm{MPa}$, WHSV $1 \mathrm{~h}^{-1}$, molar ratio of hydrogen to feedstock 100 ( $\mathrm{mol} / \mathrm{mol})$. They concluded that, at elevated pressure of 70 bar and higher temperature, the hydrodeoxygenation reaction is preferred while the hydrodecarboxylation reaction is accelerated by lowering the reaction pressure (as the number of moles of products is higher than that of reactants). Moreover, the effect of the change of reaction pressure on the product distribution is more pronounced than that of reaction temperature.

\section{Co-Processing}

Co-processing bio-oil on existing unit has become an emerging process in refineries. Although the ratio of bio-oil that was blended into petroleum was small, the influence of operating parameter on bio-oil component and the effect of bio-oil on final product quality should be understood. Necessarily pointed out, sulfur is the most common impurity to encounter and a limit in sulfur content is thought as one of the most drastic parameters that must meet with the refiners. In refineries, on the one hand, HDS aims at reaching this target while, on the other hand, co-processing with oxygenated molecules will involve HDO reactions which also consume hydrogen and might compete with HDS. Meanwhile, ammonia derived from hydrodenitrogenation not only depresses the activity of NiMo and CoMo catalysts for the conversion of sulfur in conventional hydrogenation process but also for the conversion of carboxylic and methoxy groups, but not ketones [75]. Hydrogen sulfide depresses the activity on NiMo but not on CoMo in the case of ketones. However, $\mathrm{H}_{2} \mathrm{~S}$ enhances the conversion of ester groups and is more effective than $\mathrm{CS}_{2}$ [76]. Therefore, on the one hand, $\mathrm{NH}_{3}$ and $\mathrm{H}_{2} \mathrm{~S}$ can be used to control hydrotreating. On the other hand, understanding of HDO will be helpful to co-process for the production of green oil.

\subsection{Model Compound}

Bui [77] co-processed a straight run gas oil (SRGO, S $13,500 \mathrm{ppm}$ ) crude spiked with $5000 \mathrm{ppm}$ of guaiacol that made as an oxygenated molecule representative of pyrolitic bio-oils over $\mathrm{CoMo} / \mathrm{Al}_{2} \mathrm{O}_{3}$ catalyst at the conditions of $280^{\circ} \mathrm{C}-360^{\circ} \mathrm{C}$, LHSV 1 or $2 \mathrm{~h}^{-1}$, total pressure 4 $\mathrm{MPa}$, liquid $/ \mathrm{H}_{2}$ respectively $\sim 500$. With only guaiacol probe molecule, they proposed a reaction scheme which describes the various routes leading to hydrocarbon compounds via intermediate oxygenates formation as showed in Figure 2. In the presence of SRGO and above $320^{\circ} \mathrm{C}$, complete hydrodeoxygenation (HDO) of guaiacol was observed and HDS could proceed without any further inhibition. However, they found that, at mild reaction temperature (below $320^{\circ} \mathrm{C}$ ) and reduced space velocity, an inhibition of HDS was observed.

A hydrodeoxygenation reaction scheme was presented by Senol [78] for hydrogenation of methyl heptanoate and methyl hexanoate, model compounds (3 wt\%) in m-xylene, with using commercial base catalyst $(\mathrm{NiMo} / \gamma$ $\mathrm{Al}_{2} \mathrm{O}_{3}, \mathrm{CoMo} / \gamma-\mathrm{Al}_{2} \mathrm{O}_{3}$ ) at the condition of $250 / 275 /$ $300^{\circ} \mathrm{C}, 1.5 \mathrm{MPa}, 20 \mathrm{~h}^{-1}(3 \mathrm{w} \%)$ and $\mathrm{H}_{2} /$ oil 200. They thought that aliphatic methyl esters produced hydrocarbons via three main paths: 1) the first path gave alcohols followed by dehydration to hydrocarbons; 2) deesterification yielded an alcohol and a carboxylic acid in the

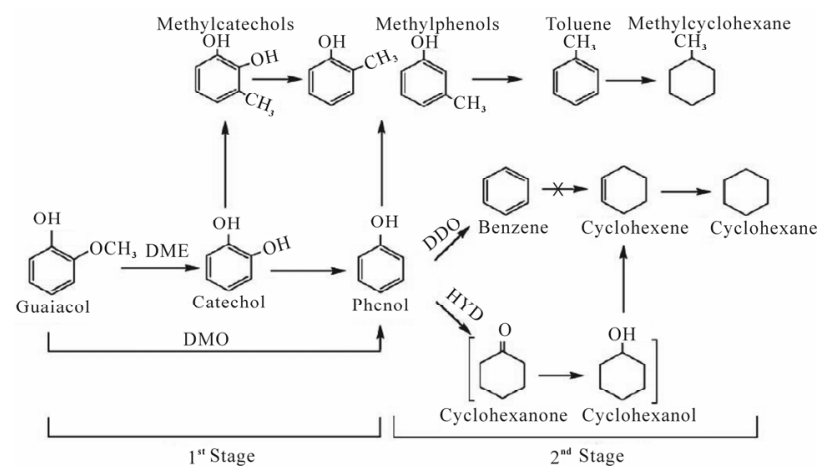

Figure 2. Reaction pathways for the conversion of guaiacol at $573 \mathrm{~K}$ under $4 \mathrm{MPa}$ of $\mathrm{H}_{2}$. 
second path; 3) carboxylic acid was further converted to hydrocarbons either directly or with an alcohol intermediate. HDO of the esters proceeds via a number of parallel and consecutive reactions. Hydrocarbons are formed as final products mainly from alcohol and/or carboxylic acid intermediates. Among them, decarboxylation of the esters led to hydrocarbons in the third path. So, Methyl esters can be hydrodeoxygenated on suphided hydrotreating catalysts under moderate conditions. The sulphided $\mathrm{NiMo} / \gamma-\mathrm{Al}_{2} \mathrm{O}_{3}$ is more active catalyst than the sulphided $\mathrm{CoMo} / \gamma-\mathrm{Al}_{2} \mathrm{O}_{3}$. Nevertheless, the stability of the catalysts was not satisfactory under the studied conditions (Figure $\mathbf{3}$ is cited in this paragraph).

\subsection{Other Vegetable Oils-Cotton Seed Oil}

In order to research hydrotreatment conversion of the esters included in refined cotton seed oil, Sebos [79] used cottonseed oil with petroleum diesel as feed to run with $\mathrm{CoMo} / \mathrm{Al}_{2} \mathrm{O}_{3}$ catalyst at the conditions of $305^{\circ} \mathrm{C}-345^{\circ} \mathrm{C}$, 30 bar, WHSV $5-25 \mathrm{~h}^{-1}$, oil/ $/ \mathrm{H}_{2} \sim 1000$ with $\sim 500 \mathrm{~h}$. The conversion of triglycerides was close to $100 \%$ with WHSV less than $5 \mathrm{~h}^{-1}$. The cetane number rasised 3 for $10 \mathrm{wt} \%$ mixture of cottonseed oil in diesel while other quality related properties are not affected. Moreover, hydrodeoxygenation is a first-order reaction with respect to the ester content and hydrodeoxygenation is temperature dependent with an activation energy of $111 \mathrm{~kJ} / \mathrm{mol}$.

\subsection{Vegetable Oil-Rapeseed Oil}

Walendziewski [80] co-processed LGO with vegetable oil on a commercial hydrorefining-hydrocracking (NiMo/ $\mathrm{Al}_{2} \mathrm{O}_{3}$ ) catalyst. They used two light gas oil-rape oil mixtures, $10 \mathrm{t} . \%$ (series 1 ) and $20 \mathrm{w} \%$ (series 2 ) rape oil with diesel oil to the tests at the condition of temperature $320 / 350 / 380^{\circ} \mathrm{C}$, hydrogen pressure $3 / 5 \mathrm{MPa}$, LHSV $2 \mathrm{~h}^{-1}$ and $\mathrm{H}_{2} /$ oil 500. It demonstrated that hydrogenolysis of ester bonds and hydrogenation of olefinic bonds in vegtable oils are the main reactions in the process. It is efficiency of hydrofining for mixed oil with rape oil as additive (10 vol\% or $20 \mathrm{vol} \%$ ) to light gas oil in the temperature range $350^{\circ} \mathrm{C}-380^{\circ} \mathrm{C}$ at hydrogen pressure $5 \mathrm{MPa}$ owning to $95 \%$ yield of hydrogenolysis and hydrogenation of ester and carboxyl acid bonds as well as hydrogenation of double bonds. Necessarily pointed out, the hydrogenation catalysts with mild hydrocracking and isomerization activities play an important role in the deep hydrorefining process in order to make rape oil into the mixture with diesel fraction. Owning to undesirable increase of CFPP for the hydrorefined products, some part of higher melting compounds can crystallize in the hydrorefined products.

\subsection{Sunflower Oil}

Huber [81] did hydrotreating of mixtures of sunflower oil/vegetable oils and vegetable oil and heavy vacuum oil (HVO). The properties of HVO feed were the following: density $0.9081 \mathrm{~g} / \mathrm{cm}^{3}$, S $0.35 \%$, N 1614 ppm, Carbon Conradson $0.15 \%$ and Distillation curve D-1160 90 vol\% 824K. They used Haldor-Topsoe TK-525 (sulfided $\mathrm{NiMo} / \mathrm{Al}_{2} \mathrm{O}_{3}, 3.9 \% \mathrm{NiO}, 18.0 \mathrm{wt} \% \mathrm{MoO}_{3}$ ) with running conditions being temperatures of $300^{\circ} \mathrm{C}-450^{\circ} \mathrm{C}$, pressure 50 bar, LHSV $5.2 \mathrm{~h}^{-1}$ and $\mathrm{H}_{2} /$ feed ratio of 1600 . All feeds appear to go through a maximum conversion at a reaction temperature of $350^{\circ} \mathrm{C}-400^{\circ} \mathrm{C}$. The test results were given as: a) the carbon molar yield of straight chain $\mathrm{C} 15$ -C18 alkanes was $71 \%$ on a carbon basis (the maximum theoretical yield of 95\%) for hydrotreating of pure vegetable oil under optimal reaction conditions; b) the rate of alkane production from pure sunflower oil was greater than the rate of HDS of a HVO with a $1.48 \mathrm{wt} \%$ sulfur content (e.g. $100 \%$ conversion of sunflower oil at $350{ }^{\circ} \mathrm{C}$ com pared to $41 \%$ of sulfur removal); c) the yield of straight chain alkanes increased when sunflower oil was mixed with HVO, illustrating that dilution of HVO can improve the reaction chemistry. Optimal conditions for co-feeding of vegetable oils with petroleum feed stocks weregiven as LHSV $5.2 \mathrm{~h}^{-1}$, and $50 \mathrm{~atm} \mathrm{H}_{2}$. Theselectivity to decarbonylation plus decarboxylation products increased with increasing temperature and sun flower oil content. Mixing the sunflower oil with HVO did not decrease the rate of desulfurization, which probably extrapolated to the use of other vegetable oils.

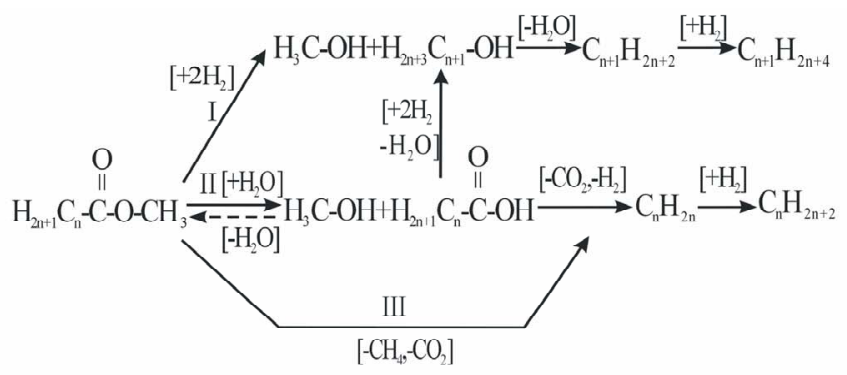

Hydrodcoxygenation reaction scheme of aliphatic methyl $\operatorname{cstcrs}(n=6$ formethyl heptanoatc and $n=5$ for methyl hexanoatc).

Figure 3. Three main paths for aliphatic methyl esters made into hydrocarbons. 


\subsection{Hydrocracking Co-Processing}

By using four vacuum gas oil (VGO) with sunflower for co-processing in hydrocracking process, Lappas etc. [82] presented the following three process schemes to produce high-quality biofuels: 1) Catalytic pyrolysis of biomass over FCC zeolitic catalysts at moderate temperatures. 2) Co-processing gas oil mixed with hydrotreated biomass pyrolysis liquids for FCC units. 3) Co-hydroprocessing vacuum gas oil (VGO) with sunflower oil. The four mixed oils were as following: mixtures of pre-hydrotreated VGO (HDT-VGO) with sunflower oil at a 70/30 and 90/10 (v/v) ratio and mixtures of straight run VGO (not hydrotreated) with sunflower oil at a 70/30 and 90/10 $(\mathrm{v} / \mathrm{v})$ ratio. The catalyst was noble metal mild-hydrocracking catalyst and test conditions were $350^{\circ} \mathrm{C}, 2000$ psig, $1.5 \mathrm{~h}^{-1}$ LHSV. The interesting conclusion was that the increase of $\mathrm{H} / \mathrm{C}$ ratio was much larger for the two feedstocks with higher amounts of bio-component (70/ 30 ), indicating that co-hydroprocessing primarily affects the heavy hydrocarbon molecules of the sunflower oil component. Oxygen removal is more effective for the two hydrotreated VGO-sunflower oil feedstocks than for the two non-treated VGO-sunflower oil feedstocks. The hydrocracking conversion of VGO-sun- flower oil mixtures is not as high as the conventional hydrocracking conversion of VGO $(60 \%-80 \%)$, suggesting that the presence of sunflower oil appears to inhibit hydrocracking conversion.

\section{Conclusions}

1) Biofuel is an oxygen containing compound. So, it is crucial for co-processing to understand the deoxygenation. Hydrotreating is an effective way to do so for co-processing with petroleum oil because it can give almost complete oil phase hydrocarbon product and promote many qualities of product.

2) Deoxygenation in hydrotreating process involves three important reaction pathways, namely hydrodecarbonylation, hydrodecarboxynation and hydrodeoxygenation. Different pathway can bring the generation of oil phase hydrocarbons. Different pathway results in difference of hydrogen consumption and reaction parameter and type of catalyst will affect them and prefer suitable way.

3) In present refinery condition, deoxygenation can be realized in extensive range of operating. Among the parameters of hydrotreating, temperature and pressure have the pronounced effects. Even though higher hydrogen pressure is helpful to degree of hydrodeoxynation, mild condition should be considered to get an economical scheme based on the cost of hydrogen and operating.

4) Catalyst plays an important role in deoxygenation by hydrotreatment. Conventional base catalysts were commonly used and various other types of catalyst were tested, including noble metal catalyst and special zeolite or support incorporated. Based on present researches, noble metal catalyst probably prefers hydrodecarbonylation while base catalyst prefers hydrodeoxygenation.

5) Co-processing mixtures of petroleum oil with biooil can produce cetane number enhanced diesel distillates while it probably causes some problem on CFPP. So, though hydrogenation process can be enough in co-processing herebefore mixtures, particularly for mixtures with small parts of bio-oil, hydroisomerization or even hydrocracking process should be more preferable.

6) On the one hand, light cycle cracking oil (LCO) can be co-processed with bio-oil and can provide an excellent blending, but severe treating conditions should be used. On the other hand, heavy gas oil (HGO) seems to have synergetic effect on co-processing with vegetable oil as the increase of $\mathrm{H} / \mathrm{C}$ ratio was much larger for the feedstock with higher amounts of bio-component $30 \%$ than that of with than bio-component $10 \%$ based on a hydrocracking co-processing research.

7) Under slightly higher hydrogen pressure the formation of aromatic hydrocarbons was suppressed. Further increase of the hydrogen partial pressure, however, suppressed the stearic acid conversion. At mild hydrogen pressure, HDS was probably inhibited by HDO.

\section{Acknowledgements}

The author thanks the colleagues of the Deven research centre of CanmetENERGY for their support and help of Jinwen Chen, senior scientist of CanmetENERGY.

\section{REFERENCES}

[1] B. Kamm, P. R. Gruber and M. Kamm, "Biorefinery Industrial Processes and Products: Status and Future Direction," Vol. 1-2, Wiley-Verlay Gmbtt and Co. KGaA, Weinheim, 2006.

[2] C. V. Stevens and R. Verhe, "Renewable Bioresources Scope and Modification for Non-Food Application," John Wiley and Sons Ltd., England, 2004.

[3] D. Puppan, "Environmental Evaluation of Biofuels," Period Polytechnica, Vol. 10, No. 1, 2002, pp. 95-116.

[4] K. S. Tyson, "Biodiesel Handling and Use Guidelines," National Renewable Energy Laboratory, Golden, 2001, p. 22. doi: $10.2172 / 787982$

[5] J. L. Shumaker, C. Crofcheck, S. A. Tackett, E. SantillanJimenez and M. Crocker; "Biodiesel Production from Soybean Oil Using Calcined Li-Al Layered Double Hydroxide Catalysts," Catalysis Letters, Vol. 115, No. 1-2, 2007, pp. 56-61. doi:10.1007/s10562-007-9071-3

[6] J. Holmgren, "Biofuels: Unlocking the Potential," ERTC 12th Annual Meeting, Barcelona, 19-21 November, 2007.

[7] N. Eisberg, "Harvesting Energy," Chemical Industries, No. 17, 2006, pp. 24-25. 
[8] European Commission (EC), "Promoting Biofuels in Europe," Directorate-General for Energy and Transport, Bruxelles, 2004, B-1049.

http://europa.eu.int/comm/dgs/energy_transport/index_en. html.

[9] Meet Clean Diesel, "Renewable Diesel Fuels". http://www.dieselforum.org

[10] G. Knothe, "Biodiesel and Renewable Diesel: A Comparison," Progress in Energy and Combustion Science, Vol. 36, No. 3, 2010, pp. 364-373. doi:10.1016/j.pecs.2009.11.004

[11] A. Centeno, E. Laurent and B. Delmon, "Influence of the Support of CoMo Sulfide Catalysts and of the Addition of Potassium and Platinum on the Catalytic Performances for the Hydrodeoxygenation of Carbonyl, Carboxylic and Guaiacol-Type Molecules," Journal of Catalysis, Vol. 154, No. 2, 1995, pp. 288-298.

[12] O. i. Şenol, T.-R. Viljava and A. O. I. Krause, "Hydrodeoxygenation of Aliphatic Esters on Sulphided Ni$\mathrm{MO} / \gamma-\mathrm{Al}_{2} \mathrm{O}_{3}$ and $\mathrm{CoMo} / \gamma-\mathrm{Al}_{2} \mathrm{O}_{3}$ Catalyst: The Effect of Water," Catalysis Today, Vol. 106, No. 1-4, 2005, pp. 186-189. doi:10.1016/i.cattod.2005.07.129

[13] O. i. Şenol, E.-M. Ryymin, T.-R. Viljava and A. O. I. Krause, "Reactions of Methyl Heptanoate Hydrodeoxygenation on Sulphided Catalysts," Journal of Molecular Catalysis A: Chemical, Vol. 268, No. 1-2, 2007, pp. 1-8. doi:10.1016/j.molcata.2006.12.006

[14] O. i. Şenol, E.-M. Ryymin, T.-R. Viljava and A. O. I. Krause, "Effect of Hydrogen Sulphide on the Hydrodeoxygenation of Aromatic and Aliphatic Oxygenates on Sulphided Catalysts," Journal of Molecular Catalysis A: Chemical, Vol. 277, No. 1-2, 2007, pp. 107-112. doi:10.1016/i.molcata.2007.07.033

[15] S. Bezergianni, A. Kalogianni and I. A. Vasalos, "Hydrocracking of Vacuum Gas Oil-Vegetable Oil Mixtures for Biofuels Production," Bioresource Technology, Vol. 100, No. 12, 2009, pp. 3036-3042. doi:10.1016/j.biortech.2009.01.018

[16] M. Ferrari, S. Bosmans, R. Maggi, B. Delmon and P. Grange, "CoMo/Carbon Hydrodeoxygenation Catalysts: Influence of the Hydrogen Sulfide Partial Pressure and of the Sulfidation Temperature," Catalysis Today, Vol. 65, No. 2-4, 2001, pp. 257-264. doi:10.1016/S0920-5861(00)00559-9

[17] M. Ferrari, R. Maggi, B. Delmon and P. Grange, "Influences of the Hydrogen Sulfide Partial Pressure and of a Nitrogen Compound on the Hydrodeoxygenation Activity of a CoMo/Carbon Catalyst," Journal of Catalysis, Vol. 198, No. 1, 2001, pp. 47-55. doi:10.1006/jcat.2000.3103

[18] G. de la Puente, A. Gil, J. J. Pis and P. Grange, "Effects of Support Surface Chemistry in Hydrodeoxygenation Reactions over CoMo/Activated Carbon Sulfided Catalysts," Langmuir, Vol. 15, No. 18, 1999, pp. 5800-5806. doi:10.1021/la981225e

[19] J. Gusmaäo, D. Brodzki, G. Djéga-Mariadassou and R. Frety, "Utilization of Vegetable Oils as an Alternative Source for Dieseltype Fuel: Hydrocracking on Educed $\mathrm{Ni} / \mathrm{SiO}_{2}$ and Sulfided $\mathrm{Ni}-\mathrm{Mo} / \gamma-\mathrm{Al}_{2} \mathrm{O}_{3}$," Catalysis Today, Vol. 5. No. 4, 1989, pp. 533-544. doi:10.1016/0920-5861(89)80017-3

[20] W. F. Maier, W. Roth, I. Thies and P. V. Ragué Schleyer, "Hydrogenolysis, IV. Gas Phase Decarboxylation of Carboxylic Acids," Chemische Berichte, Vol. 115, No. 2, 1982, pp. 808-812. doi:10.1002/cber.19821150245

[21] P. Mäki-Arvela, I. Kubičkova, M. Snare, K. Eränen and D. Y. Murzin, "Catalytic Deoxygenation of Fatty Acids and Their Derivatives," Energy and Fuels, Vol. 21, No. 1, 2007, pp. 30-41. doi:10.1021/ef060455v

[22] M. Snare, I. Kubičkova, P. Mäki-Arvela, D. Chichova, K. Eränen and D. Y. Murzin, "Catalytic Deoxygenation of Unsaturated Renewable Feedstocks for Roduction of Diesel Fuel Hydrocarbons," Fuel, Vol. 87, No. 6, 2008, pp. 933-945. doi:10.1016/j.fuel.2007.06.006

[23] P. P. Nunes, D. Brodzki, G. Bugli, G. Djega-Mariadassou, "Soybean Oil Hydrocracking under Pressure: Process and General Aspect of the Transformation," Revue De L Institut Francais Du Petrol, Vol. 41, No. 3, 1986, pp. 421-431.

[24] M. E. Halttunena, M. K. Niemeläa, A. O. I. Krausea and A. I. Vuori, "Rh/C Catalysts for Methanol Hydrocarbonylation. II. Activity in the Presence of MeI," Applied Catalysis A: General, Vol. 182, No. 1, 1999, pp. 115-123. doi:10.1016/S0926-860X(98)00361-5

[25] M. Snare, I. Kubičková, P. Mäki-Arvela, K. Eränen, J. Wärna, D. Y. Murzin, "Heterogeneous Catalytic Deoxygenation of Stearic Acid for Production of Biodiesel," Industrial \& Engineering Chemistry Research, Vol. 45, No. 16, 2006, pp. 5708-5715. doi:10.1021/ie060334i

[26] G. W. Huber and A. Corma, "Synergies between Bio- and Oil Refineries for the Production of Fuels from Biomass," Angewandte Chemie International Edition, Vol. 46, No. 38, 2007, pp. 7184-7201

[27] L. Reijnders, "Conditions for the Sustainability of Biomass Based Fuel Use," Energy Policy, Vol. 34, No. 7, 2006, pp. 863-876. doi:10.1016/j.enpol.2004.09.001

[28] L. C. Meher, D. V. Sagar and S. N. Naik, "Technical Aspects of Biodiesel Production by TransesterificationA Review," Renewable and Sustainable Energy Reviews, Vol. 10, No. 3, 2006, pp. 248-268. doi:10.1016/j.rser.2004.09.002

[29] C. Difiglio, "Using Advanced Technologies to Reduce Motor Vehicle Greenhouse Gas Emissions," Energy Policy, Vol. 25, No. 14-15, 1997, pp. 1173-1178. doi:10.1016/S0301-4215(97)00109-2

[30] J. H. Marsman, J. Wildschut, F. Mahfud and H. J. Heeres, "Identification of Components in Fast Pyrolysis Oil and Upgraded Products by Comprehensive Two-Dimensional Gas Chromatography and Flame Ionisation Detection," Journal of Chromatography A, Vol. 1150, No. 1-2, 2007, pp. 21-27. doi:10.1016/j.chroma.2006.11.047

[31] J. H. Marsman, J. Wildschut, P. Evers, S. de Koning and H. J. Heeres, "Identification and Classification of Components in Flash Pyrolysis Oil and Hydrodeoxygenated Oils by Two-Dimensional Gas Chromatography and Timeof-Flight Mass Spectrometry," Journal of Chromatography A, Vol. 1188, No. 1, 2008, pp. 17-25. doi:10.1016/j.chroma.2008.02.034 
[32] A. Oasmaa and S. Czernik, "Fuel Oil Quality of Biomass Pyrolysis Oils-State of the Art for the End-Users," Energy and Fuels, Vol. 13, No. 4, 1999, pp. 914-921. doi:10.1021/ef980272b

[33] F. de Miguel Mercader, M. J. Groeneveld, S. R. A. Kersten, N. W. J. Way, C. J. Schaverien and J. A. Hogendoorn, "Production of Advanced Biofuels: Co-Processing of Upgraded Pyrolysis Oil in Standard Refinery Units," Applied Catalysis B: Environmental, Vol. 96, No. 1-2, 2010, pp. 57-66. doi:10.1016/j.apcatb.2010.01.033

[34] J. D. Rocha, C. A. Luengo and C. E. Snape, "Hydrodexygenation of Oils from Ceelulose in Single and TwoStage Hydripyrolysis," Renewable Energy, Vol. 9, No. 1-4, 1996, pp. 950-953. doi:10.1016/0960-1481(96)88437-0

[35] P. Grange, E. Laurent, R. Maggi, A. Centeno and B. Delmon, "Hydrotreatment of Pyrolysis Oils from Biomass: Reactivity of the Various Categories of Oxygenated Compounds and Preliminary Techno-Economical study," $\mathrm{Ca}$ talysis Today, Vol. 29, No. 1-4, 1996, pp. 297-301. doi:10.1016/0920-5861(95)00295-2

[36] S. P. Zhang, Y. Yongjie, T. Li, et al. "Upgrading of Liquid Fuel from the Pyrolysis of Biomass," Bioresource Technology, Vol. 96, No. 5, 2005, pp. 545-550. doi:10.1016/j.biortech.2004.06.015

[37] Y. Xu, T. Wang, L. Ma, Q. Zhang and L. Wang, "Upgrading of Liquid Fuel from the Vacuum Pyrolysis of Biomass over the Mo-Ni $/ \gamma-\mathrm{Al}_{2} \mathrm{O}_{3}$ Catalysts," Biomass and Bioenergy, Vol. 33, No. 8, 2009, pp. 1030-1036. doi:10.1016/j.biombioe.2009.03.002

[38] Y. Xu, T. Wang, L. Ma, Q. Zhang and W. Liang, "Upgrading of the Liquid Fuel from Fast Pyrolysis of Biomass over $\mathrm{MoNi} / \gamma-\mathrm{Al}_{2} \mathrm{O}_{3}$ Catalysts," Applied Energy, Vol. 87, No. 9, 2010, pp. 2886-2891. doi:10.1016/j.apenergy.2009.10.028

[39] J. Wildschut, I. Melián-Cabrera and H. J. Heeres, "Catalyst Studies on the Hydrotreatment of Fast Pyrolysis Oil," Applied Catalysis B: Environmental, Vol. 99, No. 1-2, 2010, pp. 298-306. doi:10.1016/j.apcatb.2010.06.036

[40] M. Stumborg, A. Wong and E. Hogan, "Hydroprocessed Vegetable Oils for Diesel Fuel Improvements," Bioresource Technology, Vol. 56, No. 1, 1996, pp. 13-18. doi:10.1016/0960-8524(95)00181-6

[41] L. Avaullée, P. Duchet-Suchaux, M. Durandeu and J. N. Jaubert, "A New Approach in Correlating the Oil Thermodynamic Properties," Journal of Petroleum Science and Engineering, Vol. 30, No. 1, 2001, pp. 43-65. doi:10.1016/S0920-4105(01)00100-0

[42] C. Fragale, M. Gargano, N. Ravasio, M. Rossi and I. Santo, "Catalytic Hydrogenation of Vegetable Oils: III. A Comparison of Reactivity and Selectivity between Cyclic Polyenes and Polyunsaturated Fatty Acids with Copper Chromite as Catalyst," Inorganica Chimica Acta, Vol. 82, No. 2, 1984, pp. 157-160. doi:10.1016/S0020-1693(00)82486-X

[43] J. S. Milano-Brusco and R. Schomäcker, "Catalytic Hydrogenations in Microemulsion Systems with Rh-TPPTS: Partial Hydrogenation of Sunflower Oil," Catalysis Letters, Vol. 133, No. 3-4, 2009, pp. 273-279. doi:10.1007/s10562-009-0187-5
[44] Ullmann, "Ullmann's Encyclopedia of Industrial Chemistry," Vol. 13, Wiley-VCH Verlag GmbH \& Co., Weinheim, 2003.

[45] R. C. Christiansen, "Neste Oil Building Singapore Renewable Diesel Plant," Biodiesel Magazine, March 2009. http://www.biodieselmagazine.com/article.

[46] Schill, S.R. JAL flight to test camelina-jatropha-algae fuel. Biodiesel Magazine, January 2008. http://www.biodieselmagazine.com/article

[47] J. L. Harwood and F. D. Gunstone, "Occurrence and characterisation of oils and fats," In: F. D. Gunstone, J. L. Harwood and J. L. Dijkstra, Eds., The Lipid Handbook, CRC Press, Boca Raton, 2007, pp. 37-141.

[48] Q. Hu, M. Sommerfeld, E. Jarvis, M. Ghirardi, M, Posewitz, M. Seibert, et al., "Microalgal Triacylglycerols as Feedstocks for Biofuel Production: Erspectives and Advances," The Plant Journal, Vol. 54, No. 4, 2008, pp. 621-639. doi:10.1111/j.1365-313X.2008.03492.x

[49] A. Austin, "Boeing Planes Successfully Fly with Biofuels," Biodiesel Magazine, January 2009. http://www.biodieselmagazine.com/article

[50] J. L. Guil-Guerrero, F. Gómez-Mercado, F. García-Marotoc and P. Campra-Madrida, "Occurrence and Characterization of Oils Rich in $\gamma$-Linolenic Acid: Part I: Echium Seeds from Macaronesia," Phytochemistry, Vol. 53, No. 4, 2000, pp. 451-456. doi:10.1016/S0031-9422(99)00549-X

[51] D. Kubička, J. Chudoba, P. Šimaček, "Europacat VIII," Turku, 26-31 August 2007.

[52] N. Zeman, "Neste Oil Starts Construction on Europe's Largest Renewable Fuels Plant," Biodiesel Magazine, May 2009. http://www.biodieselmagazine.com/article

[53] M. Izadifar and M. Z. Jahromi, "Application of Genetic Algorithm for Optimization of Vegetable Oil Hydrogenation Process," Journal of Food Engineering, Vol. 78, No. 1, 2007, pp. 1-8. doi:10.1016/j.jfoodeng.2005.08.044

[54] G. N. da Rocha Filho, D. Brodzki and G. Djéga-Mariadassou "Formation of Alkanes, Alkylcycloalkanes and Alkylbenzenes during the Catalytic Hydrocracking of Vegetable Oils," Fuel, Vol. 72, No. 4, 1993, pp. 543-549. doi:10.1016/0016-2361(93)90114-H

[55] D. Kubička and L. Kaluža, "Deoxygenation of Vegetable Oils over Sulfided Ni, Mo and NiMo Catalysts," Applied Catalysis A: General, Vol. 372, No. 2, 2010, pp. 199-208. doi:10.1016/j.apcata.2009.10.034

[56] P. Šimáček, D. Kubička, G. Šebor and M. Pospíšil, "Fuel Properties of Hydroprocessed Rapeseed Oil," Fuel, Vol. 89, No. 3, 2010, pp. 611-615. doi:10.1016/j.fuel.2009.09.017

[57] P. Šimáček, D. Kubička, G. Šebor and M. Pospíšil, "Hydroprocessed Rapeseed Oil as a Source of Hydrocarbon-Based Biodiesel," Fuel, Vol. 88, No. 3, 2009, pp. 456-460. doi:10.1016/j.fuel.2008.10.022

[58] P. Šimaček and D. Kubičk, "Hydrocracking of Petroleum Vacuum Distillate Containing Rapeseed Oil: Evaluation of Diesel Fuel," Fuel, Vol. 89, No. 7, 2010, pp. 1508-1513. doi:10.1016/j.fuel.2009.09.029

[59] K. C. Kwon, H. Mayfield, T. Marolla, B. Nichols and M. Mashburn, "Catalytic Deoxygenation of Liquid Biomass 
for Hydrocarbon Fuels," Renewable Energy, Vol. 36, No. 3, 2011, pp. 907-915. doi:10.1016/j.renene.2010.09.004

[60] J. Monniera, H. Sulimmab, A. Dalaib and G. Caravaggio, "Hydrodeoxygenation of Oleic Acid and Canola Oil over Alumina-Supported Metal Nitrides," Applied Catalysis A: General, Vol. 382, No. 2, 2010, pp. 176-180. doi:10.1016/j.apcata.2010.04.035

[61] O. V. Kikhtyanin, A. E. Rubanov, A. B. Ayupov and G. V. Echevsky, "Hydroconversion of Sunflower Oil on Pd/SAPO-31 Catalyst," Fuel, Vol. 89, No. 10, 2010, pp. 3085-3092. doi:10.1016/j.fuel.2010.05.033

[62] J. Hancsók, M. Krár, S. Magyar, L. Boda, A. Holló and D. Kalló, "Investigation of the Production of High Cetane Number Bio Gas Oil from Pre-Hydrogenated Vegetable Oils over Pt/HZSM-22/ $/ \mathrm{Al}_{2} \mathrm{O}_{3}$," Microporous and Mesoporous Materials, Vol. 101, No. 1-2, 2007, pp. 148-152. doi:10.1016/j.micromeso.2006.12.012

[63] A. Guzman, J. E. Torres, L. P. Prada and M. L. Nuñez, "Hydroprocessing of Crude Palm Oil at Pilot Plant Scale," Catalysis Today, Vol. 156, No. 1-2, 2010, pp. 38-43. doi:10.1016/i.cattod.2009.11.015

[64] D. Kubička and J. Horácek, "Deactivation of HDS Catalysts in Deoxygenation of Vegetable Oils," Applied Catalysis A: General, Vol. 394, No. 1-2, 2010, pp. 9-17.

[65] E. Furimsky, "Chemistry of Catalytic Hydrogenation," Catalysis Reviews: Science and Engineering, Vol. 25, No. 3, 1983, pp. 421-458. doi:10.1080/01614948308078052

[66] E. Dorrestijn and P. Mulder, "The Radical-Induced Decomposition of 2-Methoxyphenol," Journal of the Chemical Society, Perkin Transactions, Vol. 2, 1999, 777-780. doi:10.1039/a809619h

[67] G. N. da Rocha Filho, D. Brodzki and G. Djéga-Mariadassou, "Formation of Alkanes, Alkylcycloalkanes and Alkylbenzenes during the Catalytic Hydrocracking of Vegetable Oils," Fuel, Vol. 72, No. 4, 1993, pp. 543-549. doi:10.1016/0016-2361(93)90114-H

[68] S. Echeandia, P. L. Arias, V. L. Barrio, B. Pawelec and J. L. G. Fierro, "Synergy Effect in the HDO of Phenol Over Ni-W Catalysts Supported on Active Carbon: Effect of Tungsten Precursors," Applied Catalysis B: Environmental, Vol. 101, No. 1-2, 2010, pp. 1-12. doi:10.1016/i.apcatb.2010.08.018

[69] L. Boda, G. Onyestyák, H. Solt, F. Lónyi, J. Valyon and A. Thernesz, "Catalytic Hydroconversion of Tricaprylin and Caprylic Acid as Model Reaction for Biofuel Production from Triglycerides," Applied Catalysis A: General, Vol. 374, No. 1-2, 2012, pp. 158-169. doi:10.1016/j.apcata.2009.12.005

[70] I. Kubičková, M. Snare, K. Eränen, P. Mäki-Arvela and D.Y. Murzin, "Hydrocarbons for Diesel Fuel via Decarboxylation of Vegetable Oils," Catalysis Today, Vol. 106, No. 1-4, 2005, pp. 197-200. doi:10.1016/j.cattod.2005.07.188

[71] Q. Smejkala, L. Smejkalováa and D. Kubičkab, "Thermodynamic Balance in Reaction System of Total Vegeta- ble Oil Hydrogenation," Chemical Engineering Journal, Vol. 146, No. 1, 2009, pp. 155-160.

[72] S. Vitu, R. Privat, J. N. Jaubert and F. Mutelet, "Predicting the Phase Equilibria of $\mathrm{CO}_{2}+$ Hydrocarbon Systems with the PPR78 Model (PR EOS and $k_{i j}$ Calculated through a Group Contribution Method)," The Journal of Supercritical Fluids, Vol. 45, No. 1, 2008, pp. 1-26. doi:10.1016/j.supflu.2007.11.015

[73] K. G. Joback, "A Unified Approach to Physical Property Estimation Using Multivariate Statistical Techniques," Master's Thesis, MIT, Cambridge, 1984.

[74] Q. Smejkala, L. Smejkalová and D. Kubička, "Thermodynamic Balance in Reaction System of Total Vegetable Oil Hydrogenation," Chemical Engineering Journal, Vol. 146, No. 1, 2009, pp. 155-160.

[75] E. Laurent and B. Delmon. "Study of the Hydrodeoxygenation of Carbonyl, Carboxylic and Guaiacyl Groups over Sulfided $\mathrm{CoMo} / \gamma-\mathrm{Al}_{2} \mathrm{O}_{3}$ and $\mathrm{NiMo} / \gamma-\mathrm{Al}_{2} \mathrm{O}_{3}$ Catalysts: II. Influence of Water, Ammonia and Hydrogen Sulfide," Applied Catalysis A: General, Vol. 109, No. 1, 1994, pp. 97-115. doi:10.1016/0926-860X(94)85005-4

[76] O. I. Şenol, T.-R. Viljava and A. O. I. Krause, "Effect of Sulphiding Agents on the Hydrodeoxygenation of Aliphatic Esters on Sulphided Catalysts," Applied Catalysis A: General, Vol. 326, No. 2, 2007, pp. 236-244.

[77] V. N. Bui, G. Toussaint, D. Laurenti, C. Mirodatos and C. Geantet, "Co-Processing of Pyrolisis Bio Oils and Gas Oil for New Generation of Bio-Fuels: Hydrodeoxygenation of Guaïacol and SRGO Mixed Feed," Catalysis Today, Vol. 143, No. 1-2, 2009, pp. 172-178. doi:10.1016/j.cattod.2008.11.024

[78] O. İ. Şenol, T.-R. Viljava and A. O. I. Krausede, "Hydrodeoxygenation of Methyl Esters on Sulphided $\mathrm{NiMO} / \gamma$ $\mathrm{Al}_{2} \mathrm{O}_{3}$ and $\mathrm{CoMo} / \gamma-\mathrm{Al}_{2} \mathrm{O}_{3}$ catalysts," Catalysis Today, Vol. 100, No. 3-4, 2005, pp. 331-335.

doi:10.1016/j.cattod.2004.10.021

[79] I. Sebos, A. Matsoukas, V. Apostolopoulos and N. Papayannakos, "Catalytic Hydroprocessing of Cottonseed Oil in Petroleum Diesel Mixtures for Production of Renewable Diesel," Fuel, Vol. 88, No. 3, 2009, pp. 145-149. doi:10.1016/j.fuel.2008.07.032

[80] J. Walendziewski, M. Stolarski, R. Łużny and B. Klimek, "Hydroprocesssing of Light Gas Oil-Rape Oil Mixtures," Fuel Processing Technology, Vol. 90, No. 5, 2009, pp. 686-691. doi:10.1016/i.fuproc.2008.12.006

[81] G. W. Huber, P. OConnor and A. Corma, "Processing Biomass in Conventional Oil Refineries: Production of High Quality Diesel by Hydrotreating Vegetable Oils in Heavy Vacuum Oil Mixtures," Applied Catalysis A: General, Vol. 329, No. 1, 2007, pp. 120-129. doi:10.1016/j.apcata.2007.07.002

[82] A. A. L. Lappas, S. Bezergianni and I. A. Vasalos, "Production of Biofuels via Co-Processing in Conventional Refining Processes," Catalysis Today, Vol. 145, No. 1-2, 2009, pp. 55-62. doi:10.1016/j.cattod.2008.07.001 